Article Type: Research Paper

\title{
Managerial Ability and Future Banking Performance: The Role of Book-Tax Differences as Moderator
}

\author{
Eva Herianti ${ }^{1 *}$, Arna Suryani ${ }^{2}$, and Amor Marundha ${ }^{3}$
}

\begin{abstract}
:
Research aims: This study aims to examine and analyze the effect of managerial ability on future banking performance moderated by book-tax differences.

Design/Methodology/Approach: The research samples were banks listed on the Indonesia Stock Exchange from 2014 to 2018. A purposive sampling technique was conducted to collect 108 samples of future banking performance $(t+1)$ and 81 samples of future banking performance $(t+2)$. The data were then analyzed using eviews version 10 with the ordinary least square.

Research findings: The results showed that managerial ability positively and significantly affected future banking performance $(t+1$ and $t+2)$, while book-tax differences could reduce the effect of managerial ability on future banking performance $(\mathrm{t}+1$ and $\mathrm{t}+2)$.

Theoretical contribution/Originality: This study has provided implications to the literature that managers use their abilities to achieve sustainable competitive advantage through efficient and effective use of resources. Managers need an understanding of the relationship between resources, their abilities, competitive advantages, and future earnings achievement.

Practitioner/Policy implication: Since managerial ability can increase future banking performance, this study's results may affect how companies produce managerial ability through efficient use of inputs to produce optimal output that is useful for long-term banking performance.

Research limitation/Implication: The conclusion is drawn based on various proxies to measure the managerial ability, book-tax differences, and future banking performance. Further research can develop the managerial ability proxies besides those proposed by Garcia-meca \& Garcia-Sanchez (2018).

Keywords: Managerial Ability; Book-Tax Differences; Future Banking Performance
\end{abstract}

${ }^{1}$ Department of Accounting, Faculty of Economics and Business, Universitas Muhammadiyah Jakarta, Banten, Indonesia

${ }^{2}$ Department of Accounting, Faculty of Economics, Universitas Batanghari, Jambi, Indonesia ${ }^{3}$ Department of Accounting, Faculty of Economics and Business, Universitas Bhayangkara Jakarta Raya, Jakarta Capital Special Region, Indonesia

\section{*CORRESPONDENCE:}

heriantieva@gmail.com

THIS ARTICLE IS AVAILABLE IN:

http://journal.umy.ac.id/index.php/ai

DOI: 10.18196/jai.v22i1.9997

\section{CITATION:}

Herianti, E., Suryani, A., \& Marundha, A. (2021). Managerial ability and future banking performance: the role of book-tax differences as moderator. Journal of Accounting and Investment, 22(1), 173-191.

\section{Introduction}

\section{ARTICLE HISTORY}

\section{Received:}

10 Oct 2020

Revised:

16 Nov 2020

18 Dec 2020

01 Jan 2021

Accepted:

04 Jan 2021

Many accounting scandals and financial crises that globally happened can break the shareholders' trust in the financial reports and result in some critics related to the company performance (Akeju \& Babatunde, 2017). Chang, Dasgupta, and Hilary (2010) explained that during the financial crisis, companies with limited resources experienced a lack of investment. This condition happened due to the low available resources for investment opportunities (Ivashina \& Scharfstein, 2010). Banking performance is the achievement measurement of the managers' competency in income increasing. 


\author{
Herianti, Suryani, \& Marundha \\ Managerial Ability and Future Banking Performance: The Role of Book-Tax ...
}

Selvam, Gayathri, Vasanth, Lingaraja, and Marxiaoli (2016) elucidated that banking performance is a part of organizational effectiveness covering the operational and financial results. For instance, banking issues related to the failure of Bank Mandiri's technology system have recently occurred and resulted in customer data loss, which disturbs stakeholders' concerns, especially customers and shareholders, affecting the long-term bank performance if not appropriately handled by banking management.

Salehi and Moghadam (2019) explicated that increasing the company's wealth significantly should be based on its resources and its employees' competencies. The employees' (managers') characteristics are critical in the organization and considered their competitive excellence. Managers' characteristics strongly influence studies in economic, financial, management accounting, and business practice sectors (Bertrand \& Schoar, 2003). Salehi and Moghadam (2019) stated that managerial ability is an essential part of managerial characteristics. Thus, it is essential to analyze management activities, referring to the managerial characteristics (Chang et al., 2010). Managerial characteristics are one vital company predictor to achieve its competitive excellence. The resources-based theory explains that the company's sustainable competitive excellence can be achieved when the managers can efficiently and effectively use the company resources. The use of these resources is the basis for the managers to gain the company's sustainable competitive excellence to achieve high-efficiency levels. When managers can use specific resources to achieve high-efficiency levels, they can manage the company well. The more the managers' authority, the higher the managers' ability to improve the company performance (Cheung, Naidu, Navissi, \& Ranjeeni, 2017). This condition can occur because managers with authority reveal high abilities and use their authority to provide added value to the development of company performance to maintain their position.

Demerjian, Lev, and McVay (2012) argued that a competent manager has a better ability to manage the company to earn a higher return rate and market value. A competent manager can understand the technological and industrial trends, predict the product demands, invest in projects with higher return rates, manage the employees well, and identify and utilize investment opportunities better (Demerjian et al., 2012); (Mishra, 2014). Besides, Huang, Teoh, and Zhang (2014) and Kallamu and Saat (2015) asserted that managerial ability gives positive signals in conveying the income information that the markets have positive reactions to income information issued by the company. Chang et al. (2010) affirmed that a capable manager could predict a significant projection of environmental capital expenses well without substantially deviating what to spend in the following years. Finally, going public dual-class companies with competent managers have higher growth opportunities than the single class (Nijhof \& Jeurissen, 2017).

Nevertheless, the macroeconomic condition that changes from time to time may limit the managers' ability to predict business opportunities for a future period. Therefore, this research investigated the future company performance for the next two years to reveal the managers' ability to affect future banking performance. The critical implication of macroeconomic condition changes may affect the managers to act in 


\author{
Herianti, Suryani, \& Marundha \\ Managerial Ability and Future Banking Performance: The Role of Book-Tax ...
}

managing the income opportunistically. In this case, the accounting income is different from the taxable income. Nijhof and Jeurissen (2017) described that tax planning activity contributes to providing a bigger gap between the accounting income and taxable income as well as the taxable income that contains useful information on the reported income quality.

Waluyo (2016) showed that permanent book-tax differences had a positive and significant relationship with income before tax changes, while temporary book-tax differences had a negative and significant relationship with the income before tax changes. Dechow, Ge, and Schrand (2010) explained that qualified information would be only obtained from companies with qualified income. Qualified income would give more information on the companies' relevant financial performance in their decision making. Book-tax differences would reduce the influence of managerial ability on future banking performance. This condition happens as the accounting rules give more flexibility in presenting the accounting income than the taxation regulations. Huang and Wang (2013) made clear that book-tax differences happen due to recognizing time differences between accounting principles and rules.

Managers who have skills often use their skills to serve their interests. Capable managers often take advantage of the flexibility of accounting standards to increase accounting income. Sloan (1996) stated that the increase in income reported by management could be caused by a choice of accounting methods that impact the difference between accounting income and taxable income. When there is a difference in accounting income and taxable income (book-tax differences) indicating an increase or decrease in income due to the choice of accounting method, the accrual component will show an average reversal in the coming period. This difference leads to fiscal corrections, both positive and negative corrections. A positive correction will have an impact on increasing fiscal income so that the tax burden that must be paid by the company increases. On the other hand, a negative correction will influence reducing fiscal income so that the tax burden that must be paid by the company is getting smaller. This condition will ultimately affect the future performance of banks.

This research is considered necessary as it widens the research conducted by GarcíaMeca and García-Sánchez (2018), which examined the influence of managerial ability on the financial reporting quality in banking sectors, while this research investigated the influence of managerial ability on future banking performance by involving book-tax differences as the moderating variable. García-Meca and García-Sánchez (2018) declared that their research was the first empirical research examining managerial ability in nine countries' international banking sectors.

From the methodological side, this research is considered vital since the measurement of managerial ability tends to be non-financial than the financial sectors. Besides, the previous research focused more on the capital markets in developed countries than in developing countries. This finding's implication is the importance of research on measuring managerial ability not only using the non-financial sector but also the financial sector, such as banking. It occurs because of the previous literature's 


\author{
Herianti, Suryani, \& Marundha \\ Managerial Ability and Future Banking Performance: The Role of Book-Tax ...
}

limitations that measure managerial ability in the banking sector, as found by GarcíaMeca and García-Sánchez (2018).

\title{
Literature Review and Hypotheses Development
}

Resources based view theory explains that the managers efficiently and effectively use the company resources to achieve competitive excellence (Barney, 1991). The resources used by the managers to achieve competitive excellence require the managers' understanding of the relationship between resources, managers' ability, competitive excellence, and eventually the income earned by the company in a long term period. This theory's essence is related to the company's strategic resources as the basis to gain its sustainable competitive excellence.

Simon (1945) elucidated that this theory assumes that the company maximizing the income based on its resources, and managers' ability to manage the company is basically rational. The resources owned by the company are heterogeneous and immobilized. It means that competing companies tend to have resource differences used to achieve sustainable competitive excellence. The use of the company's strategic resources is the basis to gain sustainable competitive excellence. To use the resource, the managers require an understanding of the relationship between resources, competitive excellence, and future income achievement. The managers' ability to manage the company's operational activity is obtained through experience and skill.

Competent managers have managerial abilities that are believed to be able to manage the input efficiently to produce optimal output and project future business conditions so that they can design the right strategy to optimize the use of company resources in producing output so that the company has good performance in the future.

The agency relationship between agents and principals give the opportunity to the agents to fulfill their interests. This condition happens because agents have the responsibility to manage the company so that they obtain more information than the principals (Jensen \& Meckling, 1976; Shleifer \& Vishny, 1989). This responsibility separation shows that the principals do not entirely know the agents' actions, which tend to fulfill their interests; regarding this, the principals are willing to spend more costs to monitor agents' opportunistic actions.

Besides, accounting information is known to have quality when the income is produced by a qualified company (Dechow et al., 2010). It means that income quality is considered competent to provide more information about the company's relevant financial performance in decision-making. Income is considered qualified when book-tax differences tend to be small. This condition shows that the manager poorly uses their opportunism through the gaps of the accounting principles and rules to fulfill their interests. Conversely, when book-tax differences are more dominant in a company, it denotes that the managers use their opportunistic behaviors to manage the income. 


\section{Herianti, Suryani, \& Marundha \\ Managerial Ability and Future Banking Performance: The Role of Book-Tax ...}

One factor lessening the agents' opportunistic behaviors is through the bonding mechanism. The bonding mechanism is a mechanism used by the shareholders to lessen the managers' opportunistic behaviors through remuneration (Eisenhardt, 1985), dividend division (Easterbrook, 1984), and managers' involvement in the ownership of company shares (Agrawal \& Mendelker, 1987; Jensen \& Meckling, 1976).

Further, the small book-tax difference indicates that managers can suppress opportunistic behavior from the gap between accounting principles and rules. Conversely, if the tax collection difference is more dominant in a company, managers use opportunistic behavior to manage income. This condition occurs because accounting rules provide more flexibility in presenting accounting income than tax regulations.

Book-tax differences happen when the difference occurs between the accounting income and taxable income. Huang and Wang (2013) explained that this condition could happen due to the recognition time difference between accounting principles and rules. The implication is that future performance achievement is not well fulfilled. The gap between the accounting income and taxable income significantly affects the income quality, considering the managers' opportunistic behaviors in managing the accounting income. Waluyo (2016) revealed that permanent book-tax differences had a positive and significant relationship with the income before tax changes, while temporary book-tax differences had a negative and significant relationship with income before tax changes.

Previous studies by Lev and Nissim (2004) and Hanlon (2005) have provided evidence that book-tax differences are associated with future earnings. At the same time, the association between book-tax differences and future earnings may result from nothing more than the reversal of book/tax timing differences and mean reversion of effective tax rates. Lev and Nissim (2004) suggested that book-tax differences can capture earnings management activity or that tax accounting better captures core earnings.

The banking performance specifies the managers' achievement in managing the company's business activity to realize the banking vision, missions, and goals. The managers' performance measurement is related to the actions made in various banking business activities to determine banking business sustainability. The performance measurement result can give information to the banking stakeholders. One banking performance measurement is the return of assets (ROA). ROA shows performance achievement by sacrificing certain banking assets to earn the accounting income. High ROA implies that the managers can use certain assets to earn the optimal accounting income. The ROA measurement as the performance is not only used to measure the current, but also future banking performance, such as ROA in the following year.

Jackson (2015) expounded that future earnings changes indicate future changes in annual net income. Furthermore, Jackson (2015) explained that prior studies have suggested that both types of book-tax differences are associated with earnings management and tax avoidance. The research confirmed that tax avoidance firms had a more positive association between their book-tax differences and both pretax earnings changes and tax expense changes. However, the study discovered only inconsistent 


\section{Herianti, Suryani, \& Marundha \\ Managerial Ability and Future Banking Performance: The Role of Book-Tax ...}

evidence on earnings management's influence on the association of the components of book-tax differences and future earnings changes, with results dependent on the research design.

The resources-based theory proposes that the company's sustainable competitive excellence can be achieved when the manager uses the company resources efficiently and effectively (Barney, 1991). The use of the company's strategic resources is the basis to gain sustainable competitive excellence. To use the resource, the managers require an understanding of the relationship between resources, competitive excellence, and future income achievement. The managers' ability to manage the company's operational activity is obtained through education, experience, and skill (Collins, Holcomb, Certo, Hitt, \& Lester, 2009; Kor, 2003). Managers use their ability not only to increase the financial, but also the non-financial performance (Sun, 2017); the company's internal control system effectivity (Li, 2015); to bear higher risks and willing to do more adding-value activities (Davis, Bell, Payne, \& Kreiser, 2010). Besides, managers use their ability to obtain higher credit ratings and lessen the negative effect on credit risk rating (Cornaggia, Krishnan, \& Wang, 2017); to take risks and lessen the capital expenditure but invest in the research and development projects (Yung \& Chen, 2018). Managerial ability is vital in predicting a significant environmental capital expense projection, but substantially do not deviate from what to spend in the following years (Chen \& Chen, 2019).

A competent manager is a manager who has managerial ability believed to be able to make the future business condition projection that they can design the proper strategies to optimize the utilization of company's resources in producing output, leading the company to have a good performance in the future (Yung \& Chen, 2018). Carmeli and Tishler (2006) found that managerial competence affected company performance. Besides, a competent manager is considered to have the ability to manage the shareholders' interests to gain support in fulfilling the business sustainability assumptions (Romaisyah \& Naimah, 2018), making accurate decisions to improve the company performance (Andreou, Karasamani, Louca, \& Ehrlich, 2015; Zacca \& Dayan, 2018). However, Francis, Huang, Rajgopal, and Zang (2008) uncovered that competent managers did not always increase the company's performance or significant to its financial reporting quality (Jiang, Zhu, \& Huang, 2013). This research then formulates the following hypothesis.

$\boldsymbol{H}_{1}$ : Managerial ability positively affects future banking performance.

The managers frequently face various problems in predicting future business opportunities. This condition happens due to the macroeconomic condition that changes from time to time, which the managers cannot control. Therefore, the negative implication is that future company performance cannot be controlled entirely by the managers. The future performance investigated in this research for the next two years aims at revealing the managerial ability in affecting future banking performance. Moreover, the unstable macroeconomic condition changes may affect the managers to 


\author{
Herianti, Suryani, \& Marundha \\ Managerial Ability and Future Banking Performance: The Role of Book-Tax ...
}

act in managing the income opportunistically. Thus, the income earned cannot show an accurate condition because it can reduce income quality. Huang and Wang (2013) explained that one factor which can reduce income quality is book-tax differences. Book-tax differences are differences between accounting income and taxable income. Book-tax differences happen because there is a difference in recognition time between the accounting principles and rules (Huang \& Wang, 2013). Consequently, future performance is then abandoned. Rohaya, Mastuki, and Bardai (2009) stated that tax planning activity contributes to the big gap between the accounting income and taxable income as well as the taxable income that contains useful information. Waluyo (2016) revealed that permanent book-tax differences had a positive and significant relationship with income before tax changes, while the temporary book-tax differences had a negative and significant relationship with income before tax changes.

Dechow et al. (2010) explicated that qualified information could only be obtained from companies with qualified income. That qualified income would give more information related to the company's relevant financial performance in decision making. Qualified income belongs to the book-tax differences, which tend to be small since the managers can suppress the opportunistic behaviors from the gaps between the accounting principles and rules. Conversely, when a book-tax difference is more dominant in a company, it shows that the managers use their opportunistic behaviors to manage the income. This condition takes place because the accounting rules give more flexibility in presenting the accounting income than the tax regulations. This research then formulates the following hypothesis.

$\boldsymbol{H}_{2}$ : The book-tax differences have a negative impact on the relationship between managerial ability with future banking performance.

\title{
Research Method
}

This research used the data of conventional banking financial reports listed in the Indonesia Stock Exchange from 2014 to 2018. The researchers obtained the financial reports from the www.idx.co.id site and each banking site to become the research samples. The conventional banking samples within the period of 2014-2018 were collected by the researchers using a purposive sampling technique with the following criteria: (1) conventional banking published the financial reports with the period of 2014-2018, (2) conventional banking did not experience losses. Based on the sample criteria, the researchers found 45 conventional banks listed on the Indonesia Stock Exchange during the 2014-2018 period, while 18 conventional banks suffered losses during that period, so they were excluded from the study sample. Finally, the number of research samples was 27 conventional banks. Sourced from 27 conventional banks as research data, there were 135 observations in total ( 27 banks $X 5$ years). However, future banking performance variables required data $t+1$ and $t+2$, so the observation data for $t+1$ amounted to 108 observations and $t+2$ was 81 observations. This condition occurred because 2014 data required future banking performance $(t+1)$, namely 2015; 2015 data required $t+1$, namely 2016; 2016 data required $t+1$, namely 2017; 2017 data 


\section{Herianti, Suryani, \& Marundha}

Managerial Ability and Future Banking Performance: The Role of Book-Tax ...

required $t+1$, namely 2018 . Thus, the researchers found 108 observations related to future banking performance $(t+1)$. The same condition also took place for $t+2$. It signified that 2014 data required future banking performance $(t+2)$, namely 2016; 2015 data required $t+2$, namely 2017; 2016 data required $t+2$, namely 2018. Thus, the researchers obtained 81 observations associated with future banking performance $(t+2)$.

The researchers' main reasons for using the conventional banks than the Islamic banks were that (1) conventional banks were more dominant in Indonesian capital markets, (2) conventional banks were more capital intensive as they had higher business risk than the Islamic banks, which were not income-oriented, (3) conventional banks were managed and monitored more strictly by the regulator, (4) this research's issue more dominantly led to the conventional banks' cases, such as Bank Century and Bank Mandiri. The researchers used the period of 2014-2018 for some reasons, including (1) that in this period, the macroeconomic conditions experienced fluctuation that the results could predict the income in the future period, and (2) this period was the last five years period that it could describe the current banking conditions.

This research's variables were future banking performance, managerial ability, and book-tax differences. The following is a description of the operational definition and research variable measurement.

\section{Future Banking Performance}

Selvam et al. (2016) explained that banking performance is a part of organizational effectiveness, covering the operational and financial results. The intended future banking performance in this research was the future banking performance in the next two years $(t+1$ and $t+2)$. The researchers adapted the research conducted by Salehi and Moghadam (2018) and Romaisyah and Naimah (2018) to measure future banking performance. The equation used by the researchers is as follows.

$$
E A T=\frac{\text { Net Income }}{\text { Total.Asset }}
$$

Description:

EAT: Earnings After Tax

Future banking performance was used to measure the banking efficiency in managing its resources to earn income. This higher ratio shows better banking performance in managing its resources.

\section{Managerial Ability}

Managerial ability is the managers' ability to make and implement the decisions to achieve the operational efficiency level (Demerjian, Lev, Lewis, \& McVay, 2013). The researchers adapted the research conducted by Garcia-Meca \& Garcia Sanchez (2018) to gauge banking sectors' managerial ability. The equation utilized by Garcia-Meca and Sanchez (2018) is as follows. 


\section{Herianti, Suryani, \& Marundha}

Managerial Ability and Future Banking Performance: The Role of Book-Tax ...

MAB $\theta i t=\frac{\text { Deposits+Loan+Finance Lease Investment+Interest Income }}{\text { Fixed Assets+Intangible Ascets+Interest Expense+ Labor Costs+ Operating Lense Expense }}$

Description:

MAB: Managerial Ability

This research used DEA (data envelopment analysis) to measure the managerial ability by classifying it into inputs and outputs. The inputs used were (1) fixed assets, (2) intangible assets, (3) interest expense, (4) labor costs, (5) operating lease expense, while the outputs employed were (1) deposits, (2) loan, (3) finance lease investment, and (4) interest income. The core results obtained using DEA showed managerial ability. The managerial ability score does not exceed 1 or $100 \%$. It means that a manager is considered competent if the DEA calculation score is 1 or $100 \%$.

\section{Book-Tax Differences}

Book-tax differences are the differences between accounting income and taxable income. Book-tax differences occur due to the difference of recognition time between the accounting principles and rules (Huang \& Wang, 2013). The researchers adapted the research carried out by Rohaya et al. (2009) to calculate the book-tax differences. The equation employed by Rohaya et al. (2009) to measure the book-tax differences is as follows.

$$
B T D=\frac{\text { Income Before Tax-Taxable Income }}{\text { Total Asset }}
$$

Description:

BTD: Book-Tax Differences

\section{Control Variables}

The researchers used the control variable to produce the research model quality aiming at reducing the decision-making bias. Hartono (2016) elucidated that a control variable could be used to complete or control the causality relationship to get a complete and better empirical model. The control variables included debt to equity ratio, which is the total debt divided by equity; a non-performing loan, which is the total of the nonperforming loan divided by total credit; banking age; cash flow from the operation, which is the operating cash flow divided by total assets; deposit to total liability, which is the deposits divided by total liability.

\section{Data Analysis Method}

This research employed two necessary assumption tests to obtain a BLUE research model. The assumptions were heteroscedasticity and autocorrelation. Heteroscedasticity used the Hubber-white to correct heteroscedasticity problems so that the result could be immediately used by the researchers in the hypothesis testing (Ghozali \& Ratmono, 2017). The autocorrelation test was adapted from the research 


\section{Herianti, Suryani, \& Marundha}

Managerial Ability and Future Banking Performance: The Role of Book-Tax ...

carried out by Santoso (2010), with the test result ranged from -2 to 2 so that this research model did not experience autocorrelation. The researchers did not use the normality test because the number of sample observations has fulfilled the criteria of the central limit theorem (Gujarati \& Porter, 2009). The researchers then examined the determination coefficient and research hypothesis test using the method of ordinary least square and analysis instrument of eviews 10 . The regression equations to examine both hypotheses are as follows.

Model 1 hypothesis test of future performance main effect $(t+1)$

$$
E A T t+1=\alpha+\beta 1 M A B+\beta 2 D E R+\beta 3 N P L+\beta 4 A G E+\beta 5 C F O+\beta 6 D T L+\varepsilon
$$

Model 2 hypothesis test of future performance moderation effect $(t+1)$

$$
\begin{aligned}
& E A T t+1=\alpha+\beta 1 M A B+\beta 2 B T D+\beta 3 M A B * B T D+\beta 4 D E R+\beta 5 N P L+\beta 6 A G E+\beta 7 C F O+ \\
& \beta 8 D T L+\varepsilon
\end{aligned}
$$

Model 3 additional test of future performance main effect $(t+2)$

$$
E A T t+2=\alpha+\beta 1 M A B+\beta 2 D E R+\beta 3 N P L+\beta 4 A G E+\beta 5 C F O+\beta 6 D T L+\varepsilon
$$

Model 4 additional test of future performance moderation effect $(t+2)$

$E A T t+2=\alpha+\beta 1 M A B+\beta 2 B T D+\beta 3 M A B * B T D+\beta 4 D E R+\beta 5 N P L+\beta 6 A G E+\beta 7 C F O+$ $\beta 8 D T L+\varepsilon$

Description:

EAT $_{t+1} \quad$ : Earnings After Tax $t+1$

$\mathrm{EAT}_{\mathrm{t}+2} \quad$ : Earnings After Tax $\mathrm{t}+2$

$M A B$ : Managerial Ability

BTD : Book-Tax Differences

DER : Debt to Equity Ratio

NPL : Non-Performing Loan

AGE : Age of Bank

CFO : Cash Flow from Operation

DTL : Deposit to Total Liability

\section{Result and Discussion}

This research used descriptive statistics to explain some variables in this study, namely managerial ability, book-tax differences, and future banking performance (see Table 1). Table 1 shows that the total sample at the end of this study amounted to 108, collected using the purposive sampling technique. The mean $E T_{t+1}$ was 0,0130 . This condition indicated that the banking system's future performance $(t+1)$ was $1.3 \%$ in terms of percentage. It denoted that the company's ability to manage assets to generate profit 
was $1.3 \%$. The mean $M A B$ score was 0.9626 . This value signified that the managerial ability was almost 1 , so it could be considered close to efficiency.

Table 1 Descriptive Statistics

\begin{tabular}{|c|c|c|c|}
\hline Variables & $\mathbf{N}$ & Mean & Deviation Standard \\
\hline $\mathrm{EAT} t+1$ & 108 & 0.0130 & 0.0075 \\
\hline MAB & 108 & 0.9626 & 0.0743 \\
\hline BTD & 108 & -0.0005 & 0.0037 \\
\hline DER & 108 & 6.4616 & 2.4223 \\
\hline NPL & 108 & 1.3836 & 1.0119 \\
\hline AGE & 108 & 44.6574 & 15.9831 \\
\hline CFO & 108 & 0.8617 & 7.7608 \\
\hline DTL & 108 & 0.9094 & 0.0617 \\
\hline
\end{tabular}

Description:

EAT $_{t+1} \quad$ : Earnings After Tax $t+1$

MAB : Managerial Ability

BTD : Book-Tax Differences

DER : Debt to Equity Ratio

NPL : Non-Performing Loan

AGE : Age of Bank

CFO : Cash Flow from Operation

DTL : Deposit to the total liability

Demerjian et al. (2012) explained that the value of 1 indicates managers' efficiency in managing company activities so that it is said that managers have the ability. Additionally, the BTD average was -0.0005 . This value showed that the difference between accounting profit and taxable income was $0.05 \%$. Besides, there was a mean value for the control variable used in this study, namely the DER value of 6.4616. This value revealed that the amount of equity to cover liabilities was 6.4616 . The NPL value of 1,3836 implied that loans classified as substandard in banking institutions were 1.3836. The AGE value of 44.6574 suggested that the average bank age was 44.6574 years. The CFO value of 0.8617 indicated that the bank's ability to generate cash flow from assets' availability was 0.8617 . Finally, the DTL value of 0.9094 denoted that the deposit amount against the bank's liabilities was 0.9094. In addition to descriptive statistics, the researchers also explained the correlation between this study's variables, as shown in Table 2.

Table 2 Pearson Correlation on the Research Variables

\begin{tabular}{|c|c|c|c|c|c|c|c|c|}
\hline Variables & EATt +1 & MAB & BTD & DER & NPL & $\overline{A G E}$ & CFO & DTL \\
\hline EATt+1 & 1.0000 & & & & & & & \\
\hline MAB & 0.2209 & 1.0000 & & & & & & \\
\hline BTD & -0.0781 & -0.1212 & 1.0000 & & & & & \\
\hline DER & -0.3024 & 0.0256 & 0.0495 & 1.0000 & & & & \\
\hline NPL & -0.3024 & -0.2064 & 0.0468 & 0.3724 & 1.0000 & & & \\
\hline AGE & 0.3650 & -0.0550 & -0.1934 & $\begin{array}{c}- \\
0.0837\end{array}$ & -0.0446 & 1.0000 & & \\
\hline CFO & 0.0218 & 0.0547 & -0.0011 & 0.2252 & 0.0270 & -0.1336 & 1.0000 & \\
\hline DTL & -0.2434 & 0.0734 & -0.2528 & $\begin{array}{c}- \\
0.1803\end{array}$ & -0.0558 & -0.3392 & $\begin{array}{c}- \\
0.1949\end{array}$ & 1.0000 \\
\hline
\end{tabular}




\section{Description:}

$\begin{array}{ll}\text { EAT }_{\mathrm{t}+1} & \text { : Earnings After Tax } \mathrm{t}+1 \\ \text { MAB } & \text { : Managerial Ability } \\ \text { BTD } & \text { : Book-Tax Differences } \\ \text { DER } & : \text { Debt to Equity Ratio } \\ \text { NPL } & : \text { Non-Performing Loan } \\ \text { AGE } & \text { : Age of Bank } \\ \text { CFO } & \text { : Cash Flow from Operation } \\ \text { DTL } & \text { : Deposit to the total liability }\end{array}$

Table 2 presents that the highest correlation happened between NPL and DER by 0.3724 . This condition occurred because both ratios were related to the debt level. It signified that when the level of debt was high, it had the potential to experience the non-performing loss when the risks were not well managed. Furthermore, AGE and $E A T_{t+1}$ had the second-highest correlation after NPL and DER. This condition showed that the longer the company was established, the higher the income level would be owned by future banking performance.

The hypothesis testing utilized the rules proposed by Baron and Kenny (1986) by separating the main effects (model 1 and 3 ) and moderation effects (model 2 and 4). Table 3 describes the hypothesis testing results of this research.

Table 3 Hypothesis Testing Results

\begin{tabular}{|c|c|c|c|c|c|}
\hline \multirow{3}{*}{$\begin{array}{l}\text { Independent } \\
\text { Variables }\end{array}$} & \multirow{3}{*}{$\begin{array}{l}\text { Expectation } \\
\text { Sign }\end{array}$} & \multicolumn{4}{|c|}{$\begin{array}{c}\text { Dependent Variable: EATt+1 } \\
\text { Ordinary Least Square }\end{array}$} \\
\hline & & \multicolumn{2}{|c|}{ Model 1} & \multicolumn{2}{|c|}{ Model 2} \\
\hline & & Coefficient & $t$-value & Coefficient & t-value \\
\hline MAB & + & 0.0192 & $2.7636^{* * *}$ & 0.0220 & $3.2916 * * *$ \\
\hline BTD & \pm & & & 5.3041 & $2.7968 * * *$ \\
\hline MAB*BTD & \pm & & & -5.4252 & $-2.8123 * * *$ \\
\hline DER & \pm & -0.0006 & $-2.4458^{* *}$ & -0.0006 & $-2.2369 * *$ \\
\hline NPL & \pm & -0.0022 & $-3.4727 * * *$ & -0.0022 & $-3.4346 * * *$ \\
\hline AGE & + & 0.0001 & $3.0500 * * *$ & 0.0001 & $2.5976^{* * *}$ \\
\hline CFO & + & 0.0001 & $1.8285^{*}$ & 0.0001 & $1.7470 *$ \\
\hline DTL & \pm & -0.0251 & $-2.3668 * *$ & -0.0223 & $-1.7019 *$ \\
\hline Constant & \pm & 0.0189 & 1.3943 & 0.0134 & 0.8247 \\
\hline F-value & & $11.0042^{* * *}$ & & & \\
\hline Adjusted $\mathrm{R}^{2}$ & & 0.3593 & & & \\
\hline Durbin-Watson & & 1.0721 & & & \\
\hline Stat. & & 108 & & & \\
\hline \multicolumn{6}{|l|}{ Observation } \\
\hline \multicolumn{6}{|c|}{$\begin{array}{l}\text { Description: The heteroscedasticity problem correction used the White-Hinkley }(\mathrm{HCl}) \text { heteroskedasticity } \\
\text { consistent standard errors and covariance. The problem-free autocorrelation (Santoso, 2010). }{ }^{* * *}, * * * \\
\text { significance at the level of } 10 \%, 5 \% \text { and } 1 \% \text {. }\end{array}$} \\
\hline
\end{tabular}

Description:

$\begin{array}{ll}\text { EAT }_{\mathrm{t}+1} & : \text { Earnings After Tax } \mathrm{t}+1 \\ \text { MAB } & : \text { Managerial Ability } \\ \text { BTD } & : \text { Book-Tax Differences } \\ \text { DER } & : \text { Debt to Equity Ratio }\end{array}$




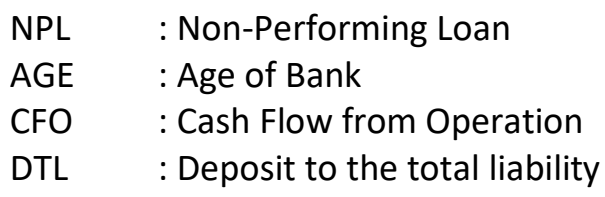

The adjusted R2 value of model 1 to model 2 experienced an increase. These conditions were ideal in accordance with the basic statistics theory that when there is an additional variable in the model, and the variable is significant, the adjusted R2 will increase. Ghozali (2013) shows that for each additional one independent variable, R2 must increase regardless of whether the variable has a significant effect on the dependent variable. Therefore, many researchers recommend using an adjusted R2 value when evaluating which regression model is best. The adjusted R2 value can go up or down if one independent variable is added to the model. Hypothesis 1 revealed that managerial ability positively affected future banking performance. The research result showed that the effect of managerial ability on future banking performance $(t+1)$ had a coefficient of 0,0192 , with a significance level of $1 \%$ (model 1 ). The research results exposed that the managerial ability positively and significantly affected future banking performance $(t+1)$. Thus, hypothesis 1 was supported. The managerial ability is the managers' ability to make and implement the decisions to achieve the operational efficiency level (Demerjian et al., 2013). Competent manager can manage the company better than the company, produce higher return rate and market value, understand the technological and industrial trends, predict the product demands, invest in the projects with higher return rate, manage the employees well, and succeed in identifying and utilizing the investment opportunities (Demerjian et al., 2012).

Managerial ability presumably can make the future business condition projections, such as designing the proper strategies to optimize the utilization of company resources in producing the outputs directing the company to have better performance in the future. The company can achieve sustainable competitive excellence when the managers efficiently and effectively use the company resources. The utilization of company strategic resources is the basis to obtain sustainable competitive excellence. Romaisyah and Naimah (2019) explained that a competent manager presumably could manage various shareholders' interests to obtain supports in fulfilling the business sustainability assumptions. Besides, Andreou et al. (2015) and Zacca and Dayan (2018) explicated that managers use the ability to make accurate decisions to improve company performance.

The importance of research on measuring managerial ability not only to use the nonfinancial sector but also the financial sector, such as banking. It occurs because the previous literature's limitations are measuring managerial ability in the banking sector, as explained by (García-Meca \& García-Sánchez, 2018). As those who manage banks, managers need managerial skills to achieve efficiency levels to improve banks' long-term performance. This condition can be identified through the minimum input sacrifice to achieve an optimal output. The inputs and outputs referred to are fixed assets, intangible assets, interest expense, labor costs, and operating lease expense, while the outputs employed were deposits, loans, finance lease investment, and interest income. Managers use their abilities to achieve sustainable competitive advantage through 


\author{
Herianti, Suryani, \& Marundha \\ Managerial Ability and Future Banking Performance: The Role of Book-Tax ...
}

efficient and effective use of resources. Therefore, managers need to understand the relationship between resources, manager's abilities, competitive advantage, and future earnings achievement. Collins et al. (2009) and Kor (2003) describe that the manager's ability to manage the company's operational activities is obtained through education, experience, and skills.

Hypothesis 2 showed that the book-tax differences reduced the effect of managerial ability on future banking performance. The research result uncovered that book-tax differences reduced the effect of managerial ability on future banking performance $(t+1)$, with the coefficient of -5.4252 at the significance level of $1 \%$ (model 2$)$. Therefore, the research result exhibited that book-tax differences reduced the effect of managerial ability on future banking performance $(t+1)$. Thus, hypothesis 2 was supported. In this case, book-tax differences are the differences between accounting income and taxable income.

Huang and Wang (2013) elucidated that book-tax differences happen due to the difference of recognition time between the accounting principles and rules. Dechow et al. (2010) explained that qualified information would only be gained from companies with qualified income. It means that qualified income information showed the information accuracy that can be used in decision-making. The income of book-tax differences, which tends to be small, shows that the managers can suppress their opportunistic behaviors through the gaps between the accounting principles and rules. Conversely, when the book-tax differences are more dominant in a company, it shows that the managers used opportunistic behaviors to manage the income. This condition happens since the accounting rules give more flexibility in presenting the accounting income than the tax regulations. In the banking context, book-tax differences are considered small, but it can reduce the effect of managerial ability on future banking performance. This condition takes place since banking is one sector that becomes the regulator's attention and capital intensive. Although book-tax differences are small, they are still able to reduce the effect of managerial ability on future banking performance. Wardana and Martani (2014) stated that book-tax differences contain information on earnings management and tax avoidance, which weakens the relevance of earnings.

\title{
Additional Testing
}

This research employed an additional test by using future banking performance $(t+2)$. Table 4 shows the additional testing results related to the research hypotheses.

The additional testing results were consistent with the previous testing results. Thus, hypothesis 1 (model 3 ) and hypothesis 2 (model 4) were supported. It signified that managerial ability positively and significantly affected future banking performance $(t+2)$, and book-tax differences reduced the effect of managerial ability on future banking performance $(t+2)$. 
Herianti, Suryani, \& Marundha

Managerial Ability and Future Banking Performance: The Role of Book-Tax ...

Table 4 The Research's Additional Testing Results

\begin{tabular}{|c|c|c|c|c|c|}
\hline \multirow{3}{*}{$\begin{array}{l}\text { Independent } \\
\text { Variables }\end{array}$} & \multirow{3}{*}{$\begin{array}{l}\text { Expectation } \\
\text { Sign }\end{array}$} & \multicolumn{4}{|c|}{$\begin{array}{c}\text { Dependent Variable: EATt+2 } \\
\text { Ordinary Least Square }\end{array}$} \\
\hline & & \multicolumn{2}{|c|}{ Model 3} & \multicolumn{2}{|c|}{ Model 4} \\
\hline & & Coefficient & t-value & Coefficient & t-value \\
\hline MAB & + & 0.0160 & $2.0330 * *$ & 0.0210 & 3.0306 \\
\hline BTD & \pm & & & 7.5820 & $2.9313 * * *$ \\
\hline$M A B * B T D$ & \pm & & & -7.9046 & $\begin{array}{c}- \\
3.0342 * * *\end{array}$ \\
\hline DER & \pm & -0.0011 & $\begin{array}{c}- \\
3.7205^{* * *}\end{array}$ & -0.0010 & $\begin{array}{c}- \\
3.2486 * * *\end{array}$ \\
\hline NPL & \pm & -0.0021 & $-2.5325^{* *}$ & -0.0022 & $\begin{array}{c}- \\
2.6595 * * *\end{array}$ \\
\hline AGE & + & 0.0001 & $3.1713^{* * *}$ & 0.0001 & $2.5315^{* *}$ \\
\hline CFO & + & 0.0001 & $1.9494 *$ & 0.0001 & $1.7279 *$ \\
\hline DTL & \pm & $-0,0286$ & $-2.4616^{* *}$ & -0.0279 & $-1.9803 * *$ \\
\hline Constant & \pm & 0,0269 & $1.8751^{*}$ & 0.0212 & 1.2802 \\
\hline F-value & & $9.0309 * * *$ & & 7.734 & $3 * * *$ \\
\hline Adjusted $\mathrm{R}^{2}$ & & 0.3759 & & & \\
\hline Durbin-Watson Stat. & & 1.0892 & & 1.1 & \\
\hline Observation & & 81 & & & \\
\hline \multicolumn{6}{|c|}{$\begin{array}{l}\text { Description: The heteroscedasticity problem correction used the White-Hinkley }(\mathrm{HCl}) \\
\text { heteroskedasticity consistent standard errors and covariance. The problem-Free } \\
\text { autocorrelation (Santoso, 2010). }{ }^{*}, * *, * * * \text { significance at the level of } 10 \%, 5 \% \text {, and } 1 \% \text {. }\end{array}$} \\
\hline
\end{tabular}

Description:

$\begin{array}{ll}\text { EATt }+2 & \text { : Earnings After Tax } t+2 \\ \text { MAB } & \text { : Managerial Ability } \\ \text { BTD } & \text { : Book-Tax Differences } \\ \text { DER } & \text { : Debt to Equity Ratio } \\ \text { NPL } & \text { : Non-Performing Loan } \\ \text { AGE } & \text { : Age of Bank } \\ \text { CFO } & \text { : Cash Flow from Operation } \\ \text { DTL } & \text { : Deposit to the total liability }\end{array}$

\section{Conclusion}

This research's findings showed the empirical evidence that banking managers used their ability to achieve a higher efficiency rate that could affect future banking performance ( $t+1$ and $t+2)$. Managerial ability is the managers' ability in making and implementing decisions to achieve the operational efficiency rate by using some inputs efficiently, such as (1) fixed assets, (2) intangible assets, (3) interest expense, (4) labor costs, (5) operating lease expense to produce optimal outputs, such as (1) deposit, (2) loan, (3) lease finance investment, and (4) interest income. Besides, the differences between the accounting income and taxable income called book-tax differences could reduce the effect of managerial ability on future banking performance $(t+1$ and $t+2)$. 


\author{
Herianti, Suryani, \& Marundha \\ Managerial Ability and Future Banking Performance: The Role of Book-Tax ...
}

This finding's implication for resources-based-view theory is that managers who perform efficiently and effectively use firm resources to achieve a competitive advantage, requiring them to understand the relationship between resources, manager capabilities, competitive advantage, and future earnings achievement. For agency theory, the small book-tax difference shows that managers can suppress their opportunistic behavior through the gap between accounting principles and rules. The difference in book-tax that is considered small, however, can reduce the effect of managerial ability on future banking performance because banking is one of the sectors that are of concern to regulators and is capital intensive so that the opportunistic behavior of managers can be suppressed. Practitioner implication is that since managerial ability could increase future banking performance, this study's results might affect how companies produce managerial ability through efficient use of inputs to produce optimal output that is useful for long-term banking performance.

This research's limitations lied in conclusions drawn based on various proxies to measure managerial ability, book-tax differences, and future banking performance. Further research can develop the managerial ability proxies beside those proposed by (García-Meca \& García-Sánchez, 2018). Further research may also discuss some other issues: first, examining the factors that form the managerial ability, such as educational level, age, experience, or managerial expertise; second, whether the markets understand the current and future implication of managerial ability owned by the managers. Therefore, further research needs to examine the effect of managerial ability on future company values in banking sectors.

\title{
References
}

Agrawal, A., \& Mandelker, G. N. (1987). Managerial incentives and corporate investment and financing decisions. The Journal of Finance, 42(4), 823-837. https://doi.org/10.1111/j.1540-6261.1987.tb03914.x

Akeju, J.B., \& Babatunde, A.A. (2017). Corporate governance and financial reporting quality in Nigeria. International Journal of Information Research and Review, 4(2), 3749-3753. Retrieved from https://www.ijirr.com/sites/default/files/issues-pdf/1586.pdf

Andreou, P. C., Karasamani, I., Louca, C., \& Ehrlich, D. (2017). The impact of managerial ability on crisis-period corporate investment. Journal of Business Research, 79, 107-122. https://doi.org/10.1016/i.jbusres.2017.05.022

Barney, J. (1991). Firm resourcses and sustained competitive advantage. Journal of Management, 17(1), 99-120. https://doi.org/10.1177\%2F014920639101700108

Baron, R. M., \& Kenny, D. A. (1986). The moderator-mediator variable distinction in social psychological research: Conceptual, strategic, and statistical considerations. Journal of Personality and Social Psychology. 51(6), 1173-1182.

Bertrand, M., \& Schoar, A. (2003). Managing with style: The effect of managers on firm policies. SSRN Electronic Journal, 1-35. https:// doi.org/10.2139/ssm. 376880

Carmeli, A., \& Tishler, A. (2006). The relative importance of the top management team's managerial skills. International Journal of Manpower. 27(1), 9-36. https://doi.org/10.1108/01437720610652817

Chang, Y. Y., Dasgupta, S., \& Hilary, G. (2010). CEO ability, pay, and firm performance. Management Science, 56(10), 1633-1652. https://doi.org/10.1287/mnsc.1100.1205 
Chen, J., \& Chen, J. (2019). Does managerial ability affect the quality of environmental financial disclosure? Sustainability Accounting, Management and Policy Journal. 11(6), 10551073. https://doi.org/10.1108/SAMPJ-09-2018-0248

Cheung, K. T. S., Naidu, D., Navissi, F., \& Ranjeeni, K. (2017). Valuing talent: Do CEOs' ability and discretion unambiguously increase firm performance. Journal of Corporate Finance, 42, 15-35. https://doi.org/10.1016/i.jcorpfin.2016.11.006

Collins, J. D., Holcomb, T. R., Certo, S. T., Hitt, M. A., \& Lester, R. H. (2009). Learning by doing: Cross-border merger and acquisitions. Journal of Business Research. 62(12), 1329-1334. https://doi.org/10.1016/i.jbusres.2008.11.005

Cornaggia, K., Krishnan, G. V., \& Wang, C. (2017). Managerial ability and credit ratings. Contemporary Accounting Research. 34(4), 2094-2122. https://doi.org/10.1111/1911-3846.12334

Davis, J. L., Greg Bell, R., Tyge Payne, G., \& Kreiser, P. M. (2010). Entrepreneurial orientation and firm performance: The moderating role of managerial power. American Journal of Business, 25(2), 41-54. https://doi.org/10.1108/19355181201000009

Dechow, P., Ge, W., \& Schrand, C. (2010). Understanding earnings quality: A review of the proxies, their determinants and their consequences. Journal of Accounting and Economics, 50(2-3), 344-401. https://doi.org/10.1016/j.jacceco.2010.09.001

Demerjian, P. R., Lev, B., Lewis, M. F., \& McVay, S. E. (2013). Managerial ability and earnings quality. Accounting Review, 88(2), 463-498. https://doi.org/10.2308/accr50318

Demerjian, P., Lev, B., \& McVay, S. (2012). Quantifying managerial ability: A new measure and validity tests. Management Science, 58(7), 1229-1248. https://doi.org/10.1287/mnsc.1110.1487

Easterbrook, F. H. (1984). Two agency-cost explanations of dividends. The American Economic Review, 74(4), 650-659.

Eisenhardt, K. M. (1985). Control: Organizational and economic approach, Management Science, 31(2), 134-149. https://doi.org/10.1287/mnsc.31.2.134

Francis, J., Huang, A. H., Rajgopal, S., \& Zang, A. Y. (2008). CEO reputation and earnings quality. Contemporary Accounting Research. 25(1), 109-147. https://doi.org/10.1506/car.25.1.4

García-Meca, E., \& García-Sánchez, I. M. (2018). Does managerial ability influence the quality of financial reporting? European Management Journal, 36(4), 544-557. https://doi.org/10.1016/j.emj.2017.07.010

Ghozali, I. (2013). Aplikasi analisis multivariate dengan program IBM SPSS 23. Semarang: Badan Penerbit Universitas Diponegoro.

Ghozali, I., \& Ratmono, D. (2017). Analisis multivariat dan ekonometrika: teori, konsep, dan aplikasi dengan eviews 10. Semarang: badan Penerbit Universitas Diponegoro.

Gujarati, D. N., \& Porter, D. C. (2009). Basic econometrics. $5^{\text {th }}$ edition. McGraw Hill Inc: New York.

Hanlon, M. (2005). The persistence and pricing of earnings, accruals, and cash flows when firms have large book-tax differences. The Accounting Review 80(1): 137-166. Retrieved from http://www.jstor.org/stable/4093164

Hartono, J. (2016). Metodologi penelitian bisnis: salah kaprah dan pengalaman-pengalaman. Edisi keenam. Yogyakarta: BPFE.

Huang, D. F., \& Wang, C. L. (2013). Book-tax differences and earnings quality for the banking industry: evidence from Taiwan. Pacific Accounting Review, 25(2), 145-164. https://doi.org/10.1108/PAR-12-2011-0052 
Huang, X., Teoh, S. H., \& Zhang, Y. (2014). Tone management. Accounting Review, 89(3), 1083-1113. https://doi.org/10.2308/accr-50684

Ivashina, V., \& Scharfstein, D. (2010). Bank lending during the financial crisis of 2008. Journal of Financial Economics, 97(3), 319-338. https://doi.org/10.1016/i.jifineco.2009.12.001

Jackson, M. (2015). Book-tax differences and future earnings changes. Journal of the American Taxation Association, 37(2), 49-73. https://doi.org/10.2308/atax-51164

Jensen, M. C., \& Meckling, W. H. (1976). Theory of the firm: Managerial behavior, agency costs and ownership structure. Journal of Financial Economics, 3(4), 305-360. https://doi.org/10.1016/0304-405x(76)90026-x

Jiang, F., Zhu, B., \& Huang, J. (2013). CEO's financial experience and earnings management. Journal of Multinational Financial Management. 23(3), 134-145. https://doi.org/10.1016/i.mulfin.2013.03.005

Kallamu, B. S., \& Saat, N. A. M. (2015). Audit committee attributes and firm performance: Evidence from Malaysian finance companies. Asian Review of Accounting, 23(3), 206231. https://doi.org/10.1108/ara-11-2013-0076

Kor, Y. Y. (2003). Experience-based top management team competence and sustained growth. Organization Science, 14(6), 707-719. https://doi.org/10.1287/orsc.14.6.707.24867

Lev, B., \& Nissim, D. (2004). Taxable income, future earnings, and equity values. The Accounting Review, 79(4), 1039-1074. https://doi.org/10.2308/accr.2004.79.4.1039

$\mathrm{Li}, \mathrm{H}$. (2015). Managerial ability and internal control quality: Evidence from China. International Journal of Financial Research, 6(2), 54-66. https://doi.org/10.5430/ijfr.v6n2p54

Mishra, D. R. (2014). The dark side of CEO ability: CEO general managerial skills and cost of equity capital. Journal of Corporate Finance, 29, 390-409. https://doi.org/10.1016/i.jcorpfin.2014.10.003

Nijhof, A. H. J., \& Jeurissen, R. J. M. (2010). The glass ceiling of corporate social responsibility. International Journal of Sociology and Social Policy, 30(11/12), 618-631. https://doi.org/10.1108/01443331011085222

Rohaya, M. D. N., Mastuki, N. A., \& Bardai, B. (2009). Bppk-tax differences and value relevance of taxable income: Malaysian evidence. Journal of Financial Reporting and Accounting, 7(2), 19-40. http://dx.doi.org/10.1108/19852510980000002

Romaisyah, L., \& Naimah, Z. (2019). The influence of managerial ability on future performance. Journal of Economics, Business, and Government Challenges, 1(2), 6-12. https://doi.org/10.33005/ebgc.v1i2.12

Salehi, M., \& Moghadam, S. M. (2019). The relationship between management characteristics and firm performance. Competitiveness Review, 29(4), 440-461. https://doi.org/10.1108/CR-11-2018-0070

Santoso, S. (2010). Statistik parametrik, konsep dan aplikasi dengan SPSS. Jakarta: PT. Gramedia. Selvam, M., Gayathri, J., Vasanth, V., Lingaraja, K., \& Marxiaoli, S. (2016). Determinants of firm performance: A subjective model. International Journal of Social Science Studies, 4(7), 90-100. https://doi.org/10.11114/ijsss.v4i7.1662

Simon, H. A. (1945). Administrative behavior. New York: Free Press.

Shleiver, A., \& Vishny, R. W. (1989). Management entrenchment: The case of managerspecific investments, Journal of Financial Economics, 25(1), 123-139. https://doi.org/10.1016/0304-405X(89)90099-8

Sloan, R. G. (1996). Do stock prices fully reflect information in accruals and cash flows about future earnings? Accounting Review, 71(3), 289-315. Retrieved from https://www.jstor.org/stable/248290 
Sun, L. (2017). Managerial ability and chemical releases. Sustainability Accounting, Management and Policy Journal, 8(3), 281-306. https://doi.org/10.1108/SAMPJ-09-2016-0062

Waluyo. (2016). The relationship between book-tax differences and earnings growth within Indonesian manufacturing firms. Research Journal of Finance and Accounting, 7(18), 127133. Retrieved from https://iiste.org/Journals/index.php/RJFA/article/view/33300

Wardana, D. P., \& Martani, D. (2014). Pengaruh Book-tax Differences dan Struktur Kepemilikan terhadap Relevansi Laba. Simposium Nasional Akuntansi XVII.

Yung, K., \& Chen, C. (2018). Managerial ability and firm risk-taking behavior. Review of Quantitative Finance and Accounting, 51(4), 1005-1032. https://doi.org/10.1007/s11156-017-0695-0

Zacca, R., \& Dayan, M. (2018). Linking managerial competence to small enterprise performance within the dynamic capability logic. Journal of Small Business and Enterprise Development, 25(2), 256-276. https://doi.org/10.1108/JSBED-02-2017-0042 